\title{
Penggunaan Objek Sejarah Dompu Sebagai Sumber Belajar di SMA Negeri 2 Woja
}

\author{
Sumiyati' ${ }^{1}$, Husnul Khatimah ${ }^{2}$ \\ 1,2 Dosen Program studi Pendidikan Sejarah, STKIP Yapis Dompu \\ E-mail: sumimaci086@gmail.com
}

\begin{abstract}
Article History: Received: 2021-07-22 || Revised: 2021-07-28 || Published: 2021-08-25
Sejarah Artikel : Diterima: 2021-07-22 || Direvisi: 2021-07-28 || Dipublikasi: 2021-08-25
\end{abstract}

\begin{abstract}
Local history objects in recent research have become a new trend in the development of teaching materials in history learning, especially the history of Bima-Dompu which is not widely exposed in textbooks such as the history of Java and other parts of Indonesia. The introduction of local historical objects is expected to provide a new color in students' insight related to history learning so that students will be closer and of course better able to understand related to history learning. The purpose of this study was to determine the effectiveness of using Dompu historical objects as a source of history learning. In this study using quantitative methods. As for the results of the research that has been done, it is known that the average value obtained by the control class is 43.8 in the pretest and 44.8 in the post test, while for the Experiment class the average value of the pretest is 52 and the post test is 73.6, so it can be concluded that the use of Dompu historical objects as learning resources in history learning can improve student learning outcomes at SMA N 02 Woja Dompu.
\end{abstract}

Keywords: History, Dompu, Interest in Learning.

\begin{abstract}
Abstrak
Objek sejarah lokal dalam penelitian yang dilakukan belakangan ini menjadi tren baru dalam pengembangan materi ajar dalam pembelajaran sejarah, khususnya Sejarah Bima- Dompu yang tidak banyak terekspos dalam buku ajar seperti sejarah Jawa dan beberapa wilayah Indonesia lainya. Pengenalan Objek sejarah local diharapkan akan memberikan warna baru dalam wawasan siswa terkait dengan pembelajaran sejarah sehingga siswa akan lebih dekat dan tentunya lebih mampu memahami terkait dengan pembelajaran sejarah. Tujuan dari penelitian ini adalah untuk mengetahui efektifitas penggunaan Objek sejarah Dompu sebagai sumber pembelajaran Sejarah. Pada penelitian ini menggunakan metode kuantitatif. Adapun hasil penelitian yang telah dilakukan adalah diketahui nilai yang diperoleh oleh kelas kontrol rata-rata 43,8 pada Pretest dan 44,8 pada nilai post test sementara untuk kelas Eksperimen diperoleh nilai rata rata pretest 52 dan post test 73,6, sehingga bisa disimpulkan bahwa penggunaan objek sejarah Dompu sebagai sumber belajar dalam pembelajaran sejarah bisa meningkatkan hasil belajar siswa di SMA N 02 Woja Dompu.
\end{abstract}

Kata kunci: Sejarah, Dompu, Minat Belajar.

\section{PENDAHULUAN}

Pendidikan merupakan suatu program dan kerja terpenting dalam kehidupan manusia. Karena dengan pendidikan dapat membentuk manusia yang berpengetahuan, berkepribadian dan memiliki keterampilan, pendidikan pada hakekatnya merupakan usaha sadar untuk mengembangkan kepribadian dan kemampuan manusia ke arah yang lebih baik, karena melalui pendidikan seseorang dapat menggali ilmu pengetahuan sebanyak-banyaknya sehingga mampu berperan aktif ditengah-tengah kehidupan. Bangsa yang berperadaban tinggi akan membuat kemajuan bagi negaranya, pendidikan merupakan syarat mutlak untuk mencapai kemajuan dalam suatu bangsa. Maju mundurnya suatu bangsa dan negara tergantung kepada maju tidaknya pendidikan pada bangsa itu sendiri, Menurut Masyhuri (2010: 30), mengatakan bahwa Pendidikan adalah suatu proses upaya yang dilakukan secara sadar dan sengaja untuk meningkatkan nilai perilaku seseorang atau masyarakat, dari keadaan tertentu ke suatu keadaan yang lebih baik. Para orang tua akan berusaha untuk memenuhi kebutuhan pendidikan anaknya agar anaknya cerdas dan mempunyai pendidikan yang baik. Hal ini sejalan dengan tujuan pemerintah yang tertuang dalam Undang-undang Republik Indonesia pada bab II dasar fungsi dan tujuan pendidikan pasal 4 (1995: 
4) yang berbunyi: "Pendidikan Nasional bertujuan mencerdaskan kehidupan bangsa dan mengembangkan manusia Indonesia seutuhnya, yaitu manusia yang beriman dan bertaqwa terhadap Tuhan Yang Maha Esa dan berbudi pekerti luhur, memiliki keterampilan, kesehatan jasmani dan rohani, kepribadian yang mantap dan mandiri serta rasa tanggung jawab kemasyarakatan dan kebangsaan.

Kabupaten Dompu merupakan salah satu kabupaten di daratan Pulau Sumbawa. Wilayah Kabupaten Dompu terbentang dari Teluk Saleh di sebelah barat, Teluk Cempi di Selatan, Teluk Sanggar dan Perbukitan Doroboha di sebelah utara. Seluruh wilayah ini membentuk Kabupaten Dompu dengan luas wilayah sekitar 2.324,55 kilometer persegi, dibandingkan dengan dua kabupaten lainnya yang terdapat di Pulau Sumbawa, wilayah Kabupaten Dompu ini relatif lebih kecil. Walaupun memiliki wilayah yang relatif kecil dibandingkan dua kabupaten lain di Pulau Sumbawa, namun keberadaan Kabupaten Dompu sebagai suatu wilayah tidak dapat dipandang sebelah mata, karena keberadaannya telah tercatat oleh bukti-bukti sejarah sejak berabad-abad lampau, Dompu sendiri merupakan salah satu wilayah yang dulunya merupakan sebuah kerajaan yang cukup terkenal dengan kekayaan alam yang dimiliki salah satunya adalah kayu sapan. Sebagai sebuah kerajaan Dompu tentu memiliki banyak peninggalan bersejarah dan peru dilakukan penelususran yang lebih serius dan bias dijadikan sebagai sumber belajar sejarah baik dalam tingkat sekolah maupun perguruan tinggi.

Pembelajaran sejarah secara umum hanya menjelaskan terkait dengan sejarah-sejarah Jawa dan wilayah lainya yang sebelumnya telah banyak ditulis. Peninggalan sejarah dapat di jadikan sumber belajar bagi pendidik dalam memberikan pembelajaran sejarah bagi peserta didik. Objek sejarah local bisa dijadikan sebagai sumber belajar dengan demikian pembelajaran sejarah diharapkan akan bermakna serta lebih menyenangkan. Sumber belajar berupa peninggalan sejarah dapat meningkatkan imajinasi peserta didik akan cerita itu sendiri, Sejarah menurut Widja adalah suatu studi yang telah dialami manusia diwaktu lampau dan telah meninggalkan jejak diwaktu sekarang, di mana tekanan perhatian diletakkan, terutama dalam pada aspek peristiwa sendiri. Dalam hal ini terutama pada hal yang bersifat khusus dan segi-segi urutan perkembangannya yang disusun dalam cerita sejarah (I Gede Widja, 1989: 9). Sementara menurut Sartono Kartodirdjo sejarah adalah gambaran tentang masa lalu manusia dan sekitarnya sebagai makhluk sosial yang disusun secara ilmiah dan lengkap. Meliputi urutan fakta masa tersebut dengan tafsiran dan penjelasan yang memberikan pengertian pemahaman tentang apa yang telah berlalu (Sartono Kartodirdjo,1982:12).

Pada pembelajaran sejarah yang di lakukan di SMA NEGERI 2 WOJA menurut hasil observasi penelitian yang telah dilakukan guru sejarah mengatakan aktivitas belajar sejarah hanya dilakukan dengan metode ceramah, cerita dan serta buku-buku bacaan yang mendominasi teorinya sehingga siswa cenderung bosan dan jenuh dalam mengikuti mata pelajaran sejarah. Selain itu pelaksanan pembelajaran sejarah yang banyak berada pada jam terakhir pembelajaran membuat suasana belajar kurang focus. Metode atau cara yang diberikan oleh guru berdampak pada minat belajar peserta didik menurun dan tidak bermotivasi untuk mempelajari materi-materi sejarah yang diberikan selain itu dampak pemberian materi seperti ini mempengaruhi daya ingat peserta didik dalam menerima materi sejarah.

Metode pengajaran sejarah hanya dilakukan di dalam kelas bahkan dengan penyampaian kurang menarik dan tidak menggunakan sumber-sumber pembelajaran yang menarik dan unik serta mudah diingat. Mereka perlu sebuah sumber belajar untuk objek sejarah Dompu agar peserta didik tertarik, mudah melihat dan memahami dan tidak membosankan, karena siswa perlu bukti bukan hanya sebuah teori dan ceramah saja. Oleh karena itu perlu ada usaha dalam upaya meningkatkan minat belajar salah satunya adalah dengan menggunakan objek sejarah local yang ada dilingkungan sekitarnya sebagai sumber belajar.

\section{METODE PENELITIAN}

Jenis penelitian yang digunakan dalam penelitian ini yaitu penelitian kuantitatif dengan pendekatan eksperimen, dimana metode eksperimen menurut Sugiyono (2012:107) metode eksperimen merupakan metode yang menjadi bagian dari metode kuantitatif. Desain eksperimen yang digunakan adalah Nonequivalent Control Group Design yang merupakan bentuk metode penelitian 
eksperimen (quasi eksperimen).

\section{HASIL DAN PEMBAHASAN}

\section{1) Pembelajaran sejarah di Sekolah}

Setelah dilakukan observasi sebagai kegiatan awal untuk mendapatkan data terkait dengan pembelajaran sejarah maka dilakukan wawancara, baik dengan Guru maupun dengan siswa, dilanjutkan dengan observasi dalam kelas selama proses pembelajaran dan melakukan pengamatan bagaimana guru mengajar, menganalisa SAP, Silabus serta sumber atau bahan ajar yang digunakan, Setelah dilakukan observasi berupa wawancara diperoleh bahwa bahan ajar yang digunakan masih merujuk hanya pada buku ajar yang dibagikan oleh sekolah, guru mata pelajaran sejarah belum melakukan inovasi dalam mengaitkan pembelajaran sejarah dengan menggunakan objek sejarah local, dan berdasarkan hasil wawncara dengan siswa, sebagian besar mereka tidak tahu tentang objek sejarah local dan bagaimana bisa terhubung dengan sejarah nasional.

Pada pembelajaran sejarah yang berlangsung di sekolah, guru lebih banyak mengandalkan buku ajar saja, tidak banyak pengembangan materi yang dilakukan bahkan dalam beberapa sub tema pebelajaran siswa diberikan tugas mengahafal peristiwa dan tokoh penting tidak ada pengayaan akan nilai-nilai yang bisa diambil dari peristiwa sejarah. Model ini menjadikan pembelajaran sejarah kering dan membosankan sebagai pembelajaran yang lebih banyak memberikan pembelajaran karakter dan nasionalisme, penggunaan objek sejarah local sebagai materi ajar dalam pembelajaran sejarah mengarahkan guru dalam berinovasi dalam menjelaskan sejarah nasional yang terikat dengan sejarah local.

\section{2) Objek sejarah Dompu}

\section{a) Doro Bata}

Doro Bata merupakan salah satu situs bersejarah, lokasi ini telah dilakukan penelitian sejak tahun 2005 sampai sekarang masih terus dilakukan penggalian, dari hasil penelusuran yang dilakukan balai Arkeologi bali menyimpulkan bahwa Doro Bata merupakan bekas Istana kerajaan Pra Islam, lokasi yang tinggi menjadikan tempat ini cukup strategis sebagai lokasi istana.

b) Makam Sultan Sirajuddin Manuru Kupang

Sultan Sirajuddin merupakan Icon pemimpin Dompu yang berani dan berdedikasi tinggi. Sejarahnya terus hidup sebagai pahlawan masyarakat Dompu secara umum. Penjajahan Belanda banyak memberikan kesengsaraan bagi rakyat Dompu, aturan dan pajak yang berat membuat masyarakat hidup dalam kesengsaraan. Sultan Sirajuddin melihat kondisi masyarakat yang sengsara melakukan perlawanan terhadap aturan dan kontrak politik ang dibuat dengan Belanda seperti tidak melakukan pemungutan pajak pada masyarakat dan memutus kontrak penjualan kayu sapan pada Belanda. Kondisi ini menyebabkan pemerintah Belanda menghukum Sultan Sirajudin dengan hukuman pembuangan dan saat itu Sultan Sirajuddin di buang ke Kupang dan menutup usia di sana sehingga mendaptkan gelar Manuru Kupang

c) Perang Sori Utu

Perang Sori Utu terjadi tahun 1941 peristiwa ini merupakan pergerakan kemerdekaan yang dilakukan oleh para pejuang Bima-Dompu dalam mengusir tentara Belanda, setelah perang Dunia 1 berakhir Jepang keluar menjadi salah satu pemenang Perang dan berusaha hadir sebagai pelindung Asia, Indonesia Khususnya Bima-Dompu saat itu sebagai wilayah kekuasaan Belanda menerima Jepang dengan tangan terbuka dan melakukan pelucutan senjata Belanda, perang sori utu pecah dengan adanya serangan balik yang dilakukan oleh tentara Belanda yang dibantu oleh Tentara Nica yang berada di Lombok Timur dan Sumbawa. Perang yang terjadi selama dua hari berakhir dengan kemenangan dari pihak lascar BimaDomu, peristiwa ini berkaitan erat dengan sejarah nasional Indonesia, perlawanan yang dilakukan lebih banyak terjadi didaerah dan berpengaruh secara nasional. 


\section{3) Penggunaan Objek Sejarah Dompu sebagai Sumber Belajar}

Penggunaan objek sejarah local cukup efektif diterapkan dalam pembelajaran sejarah hal ini terlihat setelah dilakukan penilaian dari 25 siswa kelas eksperimen dan 25 siswa kelas kontrol yang dijadikan sampel pada kelas X ips1 dan ips2, mengajarkan objek sejarah Dompu pada kelas eksperimen dengan menggunakan media pembelajaran melalui langkah-langkahnya yaitu setelah pemberian materi, mengelompokan siswa untuk diskusi kelompok, membuat pertanyaan tentang materi yang dibahas kemudian menyampaikan didepan kelas, menyajikan hasil kerja kelompok, siswa diberikan kesempatan untuk mengklarifikasi permasalahan yang belum dipahami, memberikan soal latihan berisi soal angket secara perindividu, dan menyimlpulkan materi yang dipelajari. Selanjutnya pada bagian ini hasil yang diperoleh pada penelitian ini. berdasarkan data hasil penyebaran angket pada kelas eksperimen (variabel X) mengenai penerapan objek sejarah Dompu diperoleh skor total pretest sebesar 1300 nilai rata-rata 52 sedangkan skor total pada kelas postest 1840 nilai rata rata 73,6. Dari data tersebut menunjukan bahwa pembelajaran sejarah menggunakan sumber sejarah Lokal Di SMA Negeri 2 Woja berada pada kategori baik.

Objek sejarah local sebagai sumber belajar dikatagorikan pada beberapa peninggalan sejarah yang telah masuk dalam daftar benda cagar budaya oleh Pemerintah Daerah seperti Doro Bata sebagai Peninggalan masa lampau yang diidentifikasi sebagai bekas kerajaan, kemudian Situs Doro Mpana sebagai makam masyarakat di masa lampau, makam-makam raja Dompu sebagai bukti peradaban budaya yang berkembang dimasa lampau, peninggalan bersejarah tersebut dibuat dalam materi ajar yang telah disesuikan dengan tema dan pembahasan dalam silabus pembelajaran di sekolah, dengan penerapan Objek Sejarah Dompu sebagai sumber belajar mampu meningkatkan minat belajar sejarah pada siswa. Menurut Slameto (Hariyati,2012:12), menyatakan bahwa minat sangatlah berpengaruh besar terhadap belajar, karena bila bahan pelajaran yang dipelajari tidak sesuai dengan minat siswa,siswa tidak akan belajar dengan sebaik-baiknya,karna tidak ada daya tarik bagi siswa untuk belajar. Menurut Sukardin (Susanto,2013:56), menyatakan bahwa minat dapat diartikan sebagai suatu kesukaan,kegemaran,atau kesenangan akan sesuatu.

Penggunaan Objek sejarah Dompu sebagai sumber belajar siswa mampu meningkatkan hasil belajar siswa hal tersebut bisa dilihat dengan hasil perhitungan yang diperoleh dalam penelitian ini adalah secara uji hipotesis diperoleh $t_{\text {hitung }} 2,541$ dan $t_{\text {tabel }}$ dengan $\mathrm{dk}=\mathrm{n}-2$ diperoleh 31 sampel dan taraf signifikan $0,050 \%$ atau $5 \%$ maka $t_{\text {tabel }}=0,355$. Dalam hal ini akan berlaku ketentuan bahwa apabila $t_{\text {hitung }}$ lebih kecil dari $t_{\text {tabel, }}$ maka hipotesis Ha ditolak dan bila sebaliknya maka hipotesis Ha diterima. Setelah data diolah dan dilakukan pengujian data untuk hipotesis penelitian, maka, $t_{\text {hitung }}$ lebih besar dari $t_{\text {tabel }}(18.459>1.677)$, dari perolehan hasil tersebut dan sesuai dengan syarat uji hipotesis maka hipotesis Ha diterima artinya dalam penelitian terdapat pengaruh yang signifikan antara Upaya Guru Sejarah Dalam Meningkatkan Minat Belajar Siswa Melalui Objek Sejarah Dompu Sebagai Sumber Belajar Di SMA Negeri 2 Woja Seperti yang dikemukakan oleh Riduwan (dalam Awaliyah, 2017: 60) bahwa "jika $t_{\text {hitung }} \geq t_{\text {tabel }}$ maka tolak Ho dan signifikan dan jika $t_{\text {hitung }} \leq t_{\text {tabel }}$ maka terima Ho dan tidak signifikan". Berdasarkan teori tersebut maka dapat dikemukakan bahwa hipotesis Ha diterima, artinya dapat ditarik simpulan bahwa dalam penelitian ini terdapat pengaruh yang signifikan antara Upaya Guru Sejarah Dalam Meningkatkan Minat Belajar Siswa Melalui Objek Sejarah Dompu Sebagai Sumber Belajar Di SMA Negeri 2 Woja tahun pembelajar 2019/2020.

Guru SDN 10 Pajo berpendapat bahwa pelanggaran siswa adalah perilaku menyimpang dan melanggar peraturan sekolah yang dilakukan oleh siswa, sehingga mengganggu suasana belajar dan merugikan individu lain. Hal itu, senada dengan pernyataan Willis (2005) yang menyatakan bahwa pelanggaran remaja adalah perbuatan para remaja (di bawah usia 18 tahun) yang bertentangan dengan hukum, agama, dan norma-norma masyarakat (kriminal, anti sosial, melanggar aturan) sehingga berakibat merugikan orang lain, ketenteraman umum dan juga merusak dirinya sendiri, usia siswa SD memang seluruhnya kurang dari 18 tahun sehingga antara pelanggaran siswa dan remaja dapat dianggap sama saja. Perbuatan anti sosial itu tercermin dari terganggunya suasana belajar sehingga sangat merugikan individu (siswa) lainnya. Sedangkan melanggar aturan yakni melanggar apa-apa yang sudah disepakati sebagai peraturan di sekolah. Selain itu, pendapat guru SDN 10 Pajo juga sejalan dengan pendapat 
Herlan, dkk. (2012) yang menyatakan bahwa pelanggaran remaja adalah perilaku remaja melanggar status, membahayakan diri sendiri, menimbulkan korban materi pada orang lain, dan perilaku menimbulkan korban fisik pada orang lain,merujuk pada pendapat tersebut, siswa yang melanggar peraturan sekolah jelas bahwa siswa.

\section{SIMPULAN DAN SARAN}

\section{A. Simpulan}

Berdasarkan penelitian yang telah dilakukan tentang upaya guru sejarah dalam meningkatkan minat belajar siswa melalui objek sejarah Dompu sebagai sumber belejar di SMA Negeri 2 woja Tahun Pembelajaran 2019/2020 setelah dianalisis dapat diambil kesimpulan sebagai berikut: 1) Terdapat pengaruh minat belajar siswa yang signifikan penggunaan objek sejarah Dompu sebagai sumber belajar terhadap minat belajar dengan menggunakan metode konvensional, 2) Dengan hasil uji-t diperoleh nilai $t_{\text {hitung }}$ sebesar 18.459 dan nilai $t_{\text {tabel }}$ sebesar 1,677 dengan angka signifikansi 0,05 yang berarti Objek sejarah Dompu berpengaruh terhadap minat belajar digunakan untuk melatih kemampuan berpikir kreatif peserta didik dalam sebuah pembelajaran.

\section{B. Saran}

Pembelajaran sejarah merupakan pembelajaran yang kurang diminati dan cenderung dianggap sebagai mata pelajaran yang tidak penting, namun sebenarnya mempelajari sejarah itu sangatlah menyenangkan, dalam hal ini perlu ada pembenahan dalam model dan materi yang dijarkan. Guru harus mampu berinovasi dalam meramu materi pelajaran agar lebih menarik dan bermakna sehingga siswa bisa memenuhi tujuan dari pembelajaran sejarah dan mampu mengalikasikan dalam kehidupan sehari-hari.

\section{DAFTAR RUJUKAN}

Ahmad, Susanto 2013. Teori belajar dan pembelajaran di sekolah dasar, Jakarta: kencana prenada media group.

Arikunto, Suharsimi. (2013). Prosedur Penelitian Suatu Pendekatan Praktik. Jakarta: Rineka Cipta

Dimiyati dan Mudjiono, 2013, Belajar Dan Pembelajaran, Rineka Cipta, Jakarta.

Enung Nurhasanah. (2021). Pengembangan Multimedia Pembelajaran Sejarah Perkembangan Islam Berbasis Macromedia Flash untuk Meningkatkan Hasil Belajar Mahasiswa. Ainara Journal (Jurnal Penelitian Dan PKM Bidang Ilmu Pendidikan),2(3), 148-153. Retrieved from http://journal.ainarapress.org/index.php/ainj/article/view/69

Gajalba, sidi, 1981. Pengantar sejarah Sebagai Ilmu, Jakarta: Bhatara Karya Aksara

Hamalik, Oemar, 2010. Proses Belajar Mengajar. Jakarta: Pete Bumi Aksara.

I Gede Widja (1989). Sejarah local suatu perspektif dalam pengajaran. Jakarata: Depertemen pendidikan dan kebudayaan

Putri Emilia. (2021). Upaya Meminimalisir Kenakalan Siswa Melalui Identifikasi Sebab pada Kelas XI SMA Negeri Woja Kabupaten Dompu Tahun 2018/2019. Ainara Journal (Jurnal Penelitian Dan PKM Bidang Ilmu Pendidikan), 2(1), https://doi.org/10.1234567/ainarajournal.v2i1.19

Sartono, Kartodirjo. (1982),pemikiran dan perkembangan historiografi Indonesia suatu altrnatif. Jakarta: Gramedia

Sarwono, S.W. (2001). Psikologi Remaja. Jakarta: Rajawali Pers.

Satiadarma, M.P. 2001. Respon Orang Tua Membentuk Perilaku Anak: Dampak Pygmalion di Dalam Keluarga. Jakarta: Pustaka Populer Obor.

Sitepu, B,P.2014. Pengembengan Sumber Belajar. Jakarta: Rajawali Press. 
Slameto (2010). Belajar Dan Faktor-Faktor Yang Mempengaruhinya. Jakarta: Rineka Cipta

Sudirman ,AM, 2014, Interaksi Dan Motivasi Belajar Mengajar , Jakarta: Rajawali Pers.

Sudjana, Nana, Ibrahin 2012. Penelitian Dan Penelitian Pendidikan. Bandung: Sinar Baru Algensindo

Sugiyono. (2012). Metode Penelitian Pendidikan - Pendekatan Kuantitatif, Kualitatif, Dan R\&D. Bandung: Alfabeta

Tejada, A. N. 2007. Facts For Families: Children Who Steals. USA: American Academy of Child \& Adolescent Psychiatry.

Trujillo, L.A. 2006. School Truancy: A Case Study at Successful Reduction Model In Public School. US Davis Journal of Juvenille Law \& Policy, 10(1).

Willis, S.S. 2005. Remaja dan Masalahnya (Mengupas Berbagai Bentuk Pelanggaran Remaja Seperti Narkoba, Free Sex dan Pemecahannya. Bandung: Alfabeta. 